\title{
华北陆块古生代南向增生与秦岭-桐柏-红安造山带 构造演化
}

\author{
吴元保 $\mathbb{1}^{*}$, 郑永飞 ${ }^{2}$ \\ (1) 中国地质大学(武汉)地球科学学院, 武汉 430074; \\ (2) 中国科学院壳幔物质与环境重点实验室, 中国科学技术大学地球和空间科学学院, 合肥 230026 \\ *联系人, E-mail: yuanbaowu@cug.edu.cn \\ 2013-05-30 收稿, 2013-07-08 接受, 2013-08-07 网络版发表 \\ 国家重点基础研究发展计划(2009CB825005)资助
}

\begin{abstract}
摘要 秦岭-桐柏-红安造山带记录了华南与华北陆块在古生代时期的拼合过程, 包含了华北陆 块在这个时期的三阶段南向增生. 秦岭群可能是 Rodinia 超大陆裂解过程中从华南陆块或相同构 造属性陆块分离并向北漂移到华北克拉通南缘的微陆块. 宽坪群和二郎坪群低级变质沉积岩原 岩可能是华北克拉通南缘俯冲带之上的增生楔, 在北秦岭微陆块北向俯冲过程中受到变质变形 作用. 北秦岭超高压变质岩石在寒武纪的形成可能代表了一次小陆块与大陆块之间的碰撞事件, 结果导致北秦岭地体增生到华北克拉通南缘. 秦岭群中的麻粒岩相变质作用与秦岭群广泛发育 的深熔作用和岛弧岩浆作用准同时发生，可能代表了古特提斯洋壳俯冲、弧后盆地关闭及其导致 的弧-陆碰撞事件，导致华北大陆第二次向南增生. 石炭纪高压变质作用代表了古特提斯洋壳俯 冲和第二次弧一陆碰撞事件，结果导致华北大陆第三次向南增生. 华南陆块与华北陆块之间的最 终拼合发生在三叠纪, 在西部的秦岭-桐柏-红安造山带记录了增生型弧-陆碰撞过程, 而在东部 的大别-苏鲁造山带表现为两个古老大陆之间的直接碰撞.
\end{abstract}

关键词

碰撞造山带

弧一陆碰撞

大陆增生

陆-陆碰撞

大陆俯冲
板块构造理论揭示, 造山过程涉及洋盆打开和 关闭的 Wilson 循环, 伴随着相关洋壳的俯冲和岛弧 岩浆作用、弧-陆碰撞到陆-陆碰撞过程 ${ }^{[1,2]}$. 秦岭-桐柏红安-大别-苏鲁造山带含有世界上规模最大的超高 压变质带, 是国际上研究超高压变质作用的经典地 区之一 ${ }^{[3]}$. 国内外学者对该造山带进行了 20 多年的 深人研究, 发现大陆深俯冲发生的主要时期为三叠 纪，但是在古生代时期华北与华南大陆之间存在多 期的增生拼合 ${ }^{[2,4 \sim 6]}$. 该造山带从北到南可以划分为 宽坪群、二郎坪群、秦岭群、商丹带、刘岭群、吘湾 带及南秦岭带等 7 个岩石构造单元(图 1), 其中北秦 岭由宽坪群、二郎坪群、秦岭群组成. 我们对位于该 造山带中西部的秦岭-桐柏-红安造山带进行了系统
研究, 认为该造山带在三叠纪陆壳俯冲之前存在多 期次的古特提斯洋壳俯冲和大陆增生/碰撞过程, 由 此进一步限定了复合型大陆碰撞造山带的多期构造 演化历史.

宽坪群以洛南-栾川断裂为界与华北克拉通相连, 主要出露有云母片岩、石英岩、大理岩和角闪岩等, 变质等级主要为绿片岩相-低角闪岩相, 局部可达角 闪岩相. 变沉积岩中碎屑锆石的 U-Pb 年龄主要集中 在 $0.8 \sim 1.0,1.2 \sim 1.7$ 和 $2.4 \sim 2.6 \mathrm{Ga}^{[2]}$, 显示宽坪群的物 源主要来自华南陆块或具有相似构造属性的陆块, 这样华北克拉通的南缘应该在宽坪群以北. 碎屑岩 浆锆石的最年轻 U-Pb 年龄为约 $600 \mathrm{Ma}$, 代表了这些 沉积岩的最大沉积时代. 宽坪群中的绿片岩具有

引用格式: 吴元保, 郑永飞. 华北陆块古生代南向增生与秦岭-桐柏-红安造山带构造演化. 科学通报, 2013, 58: 2246-2250 Wu Y B, Zheng Y F. Southward accretion of the North China Block and the tectonic evolution of the Qinling-Tongbai-Hong'an orogenic belt. Chin Sci Bull, 2013, 58: 2246-2250, doi: 10.1360/972013-662 
N-MORB 或 E-MORB 型的微量元素分布特征, 其原 岩年龄分别报道有 $943 \pm 6 \mathrm{Ma}^{[7]}$ 到 $611 \pm 18 \mathrm{Ma}^{[8]}$, 说明 它们来自新元古代裂谷或弧后玄武岩(图 2(a)). 宽坪 群的区域变质年龄可能不晚于约 $440 \mathrm{Ma}^{[9,10]}$, 应该出 现在寒武纪，对应于这些沉积岩受到俯冲并增生到 华北克拉通南缘的时代.

二郎坪群主要由中基性变质火山岩和变沉积岩 组成. 这些变质火山岩具有 E-MORB 或岛弧岩浆岩 的微量元素特征, 表明它们形成于岛弧 ${ }^{[12]}$ 或弧后盆 地 ${ }^{[6]}$ 环境. 同位素年代学和地球化学数据显示, 一些 具有岛弧性质的火山岩被约 480 490 Ma 的花岗岩侵 人, 表明这些岛弧火山岩的形成时代早于约 490 $\mathrm{Ma}^{[12]}$. 对二郎坪约 $440 \mathrm{Ma}$ 辉长岩的元素和同位素地 球化学研究表明, 它们可能形成于弧后盆地环境 ${ }^{[13]}$. 结合北秦岭超高压变质作用的时代以及商丹洋在约 400 450 Ma 时的向北俯冲, 我们认为二郎坪群的基 底形成可能是在约 $490 \mathrm{Ma}$ 之前秦岭群向北增生过程 中形成的岛弧火山岩及其沉积盖层(图 2(b)), 在约 $450 \mathrm{Ma}$ 之后由于商丹洋的北向俯冲演化为弧后盆 地 ${ }^{[4]}$ (图 2(d)).

秦岭群主要有榴辉岩、片岩、片麻岩、麻粒岩和 大理岩等 ${ }^{[14]}$. 在榴辉岩和片麻岩中发现有柯石英 ${ }^{[14]}$ 和金刚石包裹体 ${ }^{[15]}$, 指示这些岩石经历了峰期压力 在 $3.3 \mathrm{GPa}$ 以上的超高压变质作用. 但是, 矿物温压 计计算获得变质峰期温压条件分别为 $680 \sim 770{ }^{\circ} \mathrm{C}$ 和2.25 2.80 $\mathrm{GPa}^{[16,17]}$, 均低于柯石英和金刚石的稳 定温压条件，可能指示这些超高压岩石经历了强烈 的退变质作用改造. 麻粒岩相变质在秦岭群广泛报 道, 其峰期温压条件分别为 $760 \sim 840{ }^{\circ} \mathrm{C}$ 和 950 980 $\mathrm{MPa}^{[9]}$. 碎屑锆石 U-Pb 年代学研究表明, 秦岭群以发 育新元古代 $960 \mathrm{Ma}$ 主年龄峰为特征, 明显区别于华 北陆块, 因此可能不是华北克拉通南缘格林维尔期 的活动大陆边缘 ${ }^{[18]}$; 以缺少新元古代中期约750 Ma 年龄峰区别于华南陆块 ${ }^{[2]}$. 锆石 U-Pb 年代学和岩石 地球化学结果显示, 秦岭群内高压-超高压榴辉岩原 岩形成于约 $800 \mathrm{Ma}$, 具有大陆拉斑玄武岩的特征, 来自相对亏损的地幔源区 ${ }^{[13]}$. 由于这些榴辉岩的原 岩与二郎坪群玄武岩明显不同, 而与华南陆块北缘 同期大陆裂谷玄武岩相类似，指示榴辉岩原岩形成 于新元古代大陆裂谷环境. Wang 等人 ${ }^{[19]}$ 对北秦岭榴 辉岩中进行了详细的锆石 U-Pb 定年、微量元素和包 裹体矿物分析, 将榴辉岩变质时代限定在485 495 Ma.
这个结果得到了榴辉岩石榴石 + 全岩 Lu-Hf 等时线定 年结果的确证 ${ }^{[17]}$. 因此, 秦岭群可能是 Rodinia超大陆 裂解过程中从华南陆块或相似构造属性陆块分离 $[13,20]$ 并向北漂移到华北克拉通南缘的微陆块(图2(a)). (北) 秦岭超高压变质岩石的形成可能代表了一次大陆碰撞 事件(图2(c)), 伴有大陆边缘加积楔沉积物的变形和 变质作用, 形成现在出露的宽坪群低级变质岩. 虽然 受到后期变质作用的改造, 但是这期寒武纪变质变形 作用在宽坪群岩石中的记录还是明显的.

在秦岭群发育有两期麻粒岩相变质作用. 其中 以松树沟地区高压麻粒岩为代表的一期麻粒岩相变

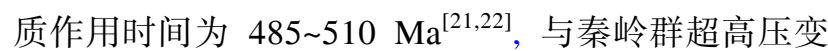
质作用的时间几乎重叠. 这些麻粒岩产出于橄榄岩 的周围, 可能是深俯冲地壳物质受到地幔楔加热引 起麻粒岩相变质作用, 结果橄榄岩与高压变质岩共 生. 秦岭群中还存在年龄为 410 440 Ma 的一期麻粒 岩相变质作用 ${ }^{[9,23]}$. 这期麻粒岩相变质作用与秦岭群 广泛发育的深熔作用和岛弧岩浆作用近似同时 ${ }^{[2]}$. 这 些岩浆岩部分具有正的锆石 $\varepsilon_{\mathrm{Hf}}(t)$ 和全岩 $\varepsilon_{\mathrm{Nd}}(t)$ 值、低 的全岩 $\left({ }^{87} \mathrm{Sr} /{ }^{86} \mathrm{Sr}\right)_{\mathrm{i}}$ 值，指示这一时期伴有新生地壳的 生长和再造. 这一期构造作用代表了商丹洋壳俯冲 和第一次弧-陆碰撞事件, 商丹缝合带上的岛弧岩浆 岩及伴生的沉积岩逆冲至秦岭群, 结果导致华北陆 块第二次向南增生(图 2(d)). 这期变质 作用和岩浆 事件在宽坪和二郎坪群也有记录 ${ }^{[10]}$, 它们可能是商 丹洋壳北向俯冲过程中弧后拉张加热的结果 ${ }^{[2]}$.

对红安造山带北部湤湾高压变质带的榴辉岩, 在详细岩石学研究的基础上进行了 LA-(MC)-ICPMS 锆石 U-Pb 定年、微量元素和 Hf 同位素组成分析, 确 定出该地区存在约 310 320 Ma 俯冲的古特提斯洋壳, 洋壳的形成时间为 $406 \pm 5 \sim 420 \pm 7 \mathrm{Ma}^{[24 \sim 26]}$. 锆石 $\mathrm{Hf}$ 同位素分析得到, 它们既有接近亏损地幔的高 $\varepsilon_{\mathrm{Hf}}(t)$ 值，对应于古特提斯洋壳玄武岩; 也有负的 $\varepsilon_{\mathrm{Hf}}(t)$ 值, 反映了古老地壳沉积物的加人. 该地区古生代洋壳 可能形成于华南陆块北部的边缘盆地环境, 是秦岭 微陆块与华北克拉通碰撞拼合后在其南缘发生构造 伸展作用的结果(图 2(d)). 同时, 对于原岩为典型华 南陆块新元古代基底物质的高压变质岩石, 它们发 生高压榴辉岩相变质作用的时间也为 $310 \sim 320 \mathrm{Ma}$, 表明陆壳岩石和洋壳岩石一起共同经历了石炭纪榴 辉岩相变质作用, 陆壳俯冲岩石对于洋壳榴辉岩的 抬升和保存可能起了关键作用. 因此, 310 320 Ma 的 


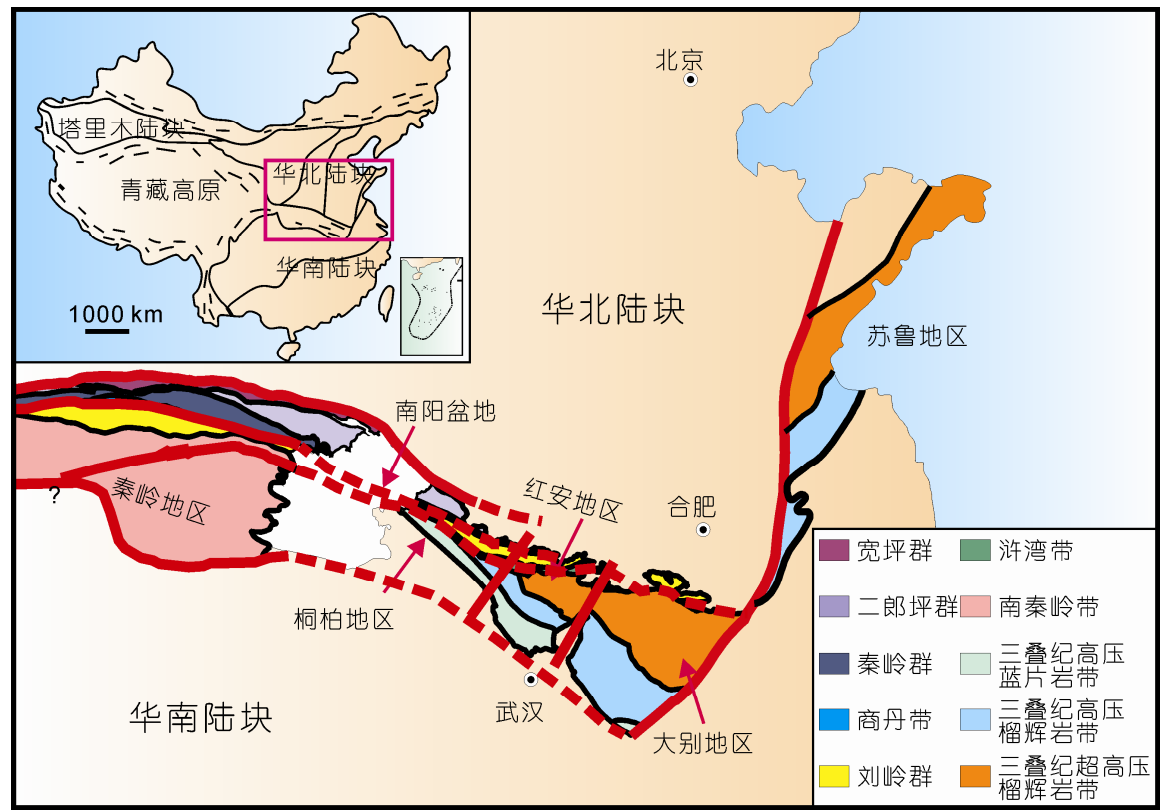

图 1 秦岭-桐柏-红安-大别-苏鲁造山带地质简图(据 Zheng 等人 ${ }^{[11]}$ 修改)

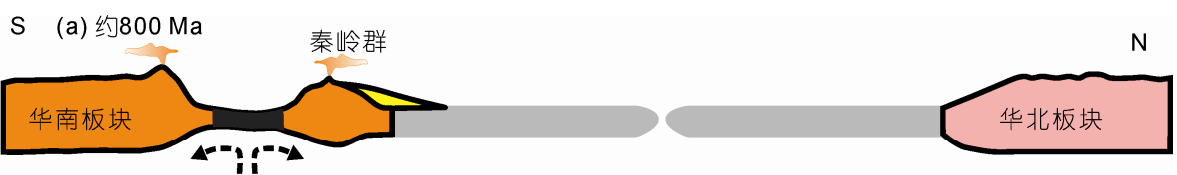

(b) 大于 $490 \mathrm{Ma}$
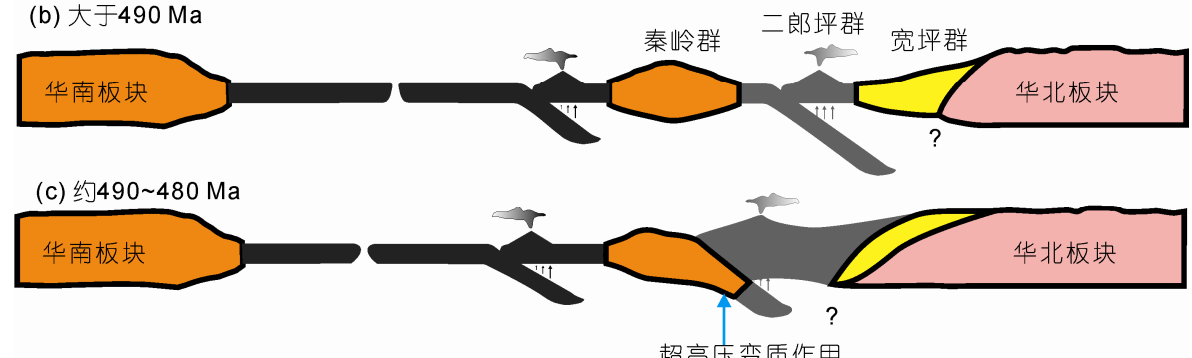

(d) 约450 400 Ma

二郎坪弧后盆地打开

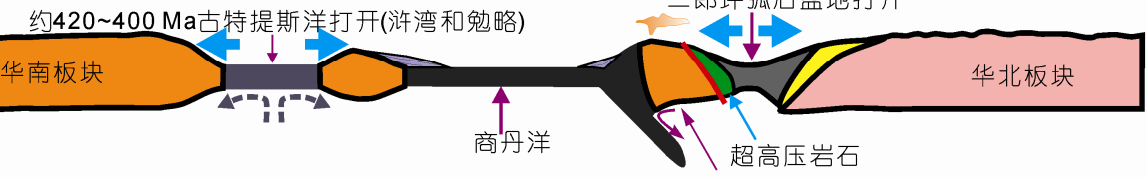

(e) 约320 300 Ma

麻粒岩、混合岩和花岗岩

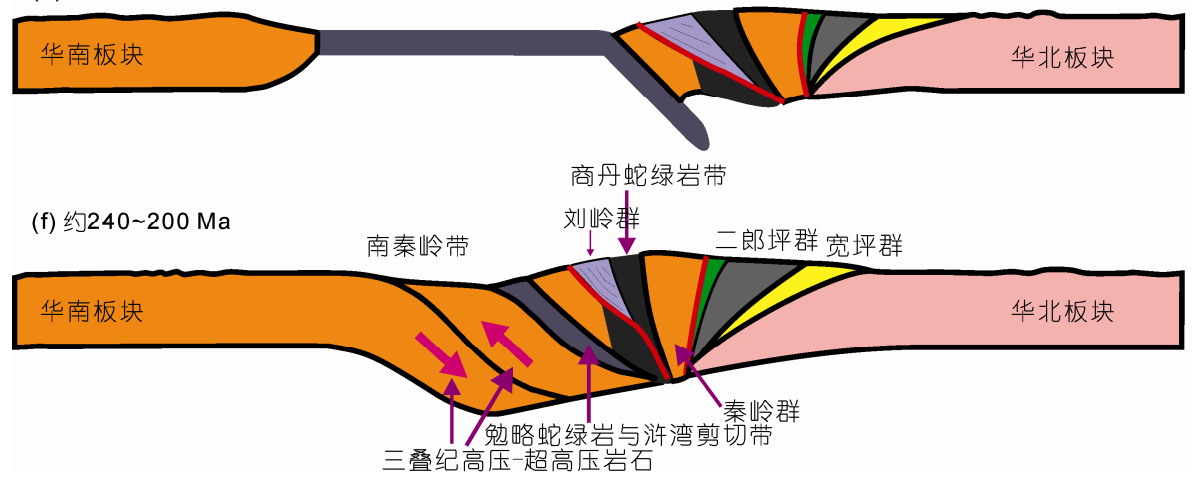

图 2 华南与华北陆块沿秦岭-桐柏-红安造山带构造拼合过程示意图(据 $\mathbf{W u}$ 和 Zheng ${ }^{[2]}$ 修改) 
构造作用代表了古特提斯洋壳玄武岩及其上覆陆源 沉积物俯冲和第二次弧-陆碰撞事件, 相应的洋壳玄 武岩和沉积物拼贴到商丹缝合带的南缘, 结果华北 大陆第三次向南增生(图 2(e)). 石炭纪的变质作用在 桐柏造山带的信阳群和秦岭造山带的刘岭群均有报 道 ${ }^{[9,27]}$, 但是没有达到榴辉岩相. 其中信阳群经历了 中压变质作用, 石炭纪的变质作用发生在古特提斯 洋壳俯冲过程中的上盘 ${ }^{[9]}$, 因此古特提斯洋壳的俯冲 可能可以向西延伸至南秦岭带的北缘.

华南陆块与华北陆块之间的最终拼合发生在三 叠纪中期的 220 240 Ma (图 2(f)), 这在红安-大别-苏 鲁造山带表现为超高压变质岩的形成 ${ }^{[11,28 ~ 30]}$, 而三 叠纪超高压变质岩在秦岭-桐柏造山带尚未发现 ${ }^{[2]}$. 就这个复合型碰撞造山带来说, 东部大陆碰撞属于 华南华北两个古老大陆之间的直接碰撞, 所形成的 大别-苏鲁造山带内部缺乏新生岛弧地体, 因此造山 带本身相对狭窄; 而西部大陆碰撞属于新增生到华 北克拉通南缘的微陆块/岛弧地体与华南古老大陆之 间的碰撞, 所形成的秦岭-桐柏造山带内部存在新生 岛弧地体, 因此造山带本身相对宽阔 ${ }^{[3]}$. 红安造山带
位于两者之间，其东部表现出与大别-苏鲁造山带相 似的特点, 而西部表现出与秦岭-桐柏造山带相似的 特点, 因此记录了从特提斯洋壳俯冲到大陆碰撞的 一系列构造过程及其转换.

通过对秦岭-桐柏-红安-大别造山带中榴辉岩、麻 粒岩及相关高级变质岩石的同位素年代学和地球化 学研究, 揭示出在三叠纪大陆深俯冲之前, 东秦岭桐柏-红安造山带出现过三期大陆增生作用: 第一期 为秦岭微陆块增生到华北克拉通南缘, 引起约 480 $490 \mathrm{Ma}$ 的超高压变质作用; 第二期为秦岭微陆块与 早古生带岛弧之间的碰撞作用，引起约 420 430 Ma 的麻粒岩相变质以及相应的岩浆作用; 第三期为古 特提斯洋壳俯冲导致的弧-陆碰撞, 引起了约 310 $320 \mathrm{Ma}$ 的高压榴辉岩相变质作用. 东秦岭-桐柏-红 安造山带记录了华北陆块在古生代时期的 3 次南向 增生过程, 前后持续了 $300 \mathrm{Ma}$ 以上, 最终在三叠纪 与华南陆块碰撞成一体. 在这个复合型造山带的东 西部之间，变质作用等级和变质作用时间上存在一 定的差异, 可以解释为华南陆块自东向西斜向俯冲 和华南-华北大陆逐渐碰撞的结果 ${ }^{[31 ~ 33]}$.

\section{参考文献}

1 Zheng Y F. Metamorphic chemical geodynamics in continental subduction zones. Chem Geol, 2012, 328: 5-48

2 Wu Y B, Zheng Y F, Tectonic evolution of a composite collision orogen: An overview on the Qinling-Tongbai-Hong'an-Dabie-Sulu orogenic belt in central China. Gondwana Res, 2013, 23: 1402-1428

3 Zheng Y F, Xiao W J, Zhao G C. Introduction to tectonics of China. Gondwana Res, 2013, 23: 1189-1206

4 Zhang G W, Yu Z P, Sun Y, et al. The major suture zone of the Qinling orogenic belt. J Southeast Asian Earth Sci, 1989, 3: 63-76

5 Ratschbacher L, Hacker B R, Calvert A, et al. Tectonics of the Qinling (Central China): Tectonostratigraphy, geochronology, and deformation history. Tectonophysics, 2003, 366: 1-53

6 Dong Y P, Zhang G W, Neubauer F, et al. Tectonic evolution of the Qinling orogen, China: Review and synthesis. J Asian Earth Sci, 2011, 41: 213-237

7 Diwu C R, Sun Y, Liu L A, et al. The disintegration of Kuanping Group in North Qinling orogenic belts and Neo-proterozoic N-MORB. Acta Petrol Sin, 2010, 26: 2025-2038

8 Yan Q R, Wang Z Q, Yan Z, et al. Timing of the transformation from seafloor spreading on the south margin of the North China Block to subduction within the North Qinling orogenic belt. Acta Geol Sin, 2009, 84: 1563-1583

9 Liu X C, Jahn B M, Hu J, et al. Metamorphic patterns and SHRIMP zircon ages of medium- to high-grade rocks from the Tongbai orogen, central China: Implications for multiple accretion/collision processes prior to terminal continental collision. J Metamorph Geol, 2011, 29: 979-1002

10 Liu X C, Jahn B M, Li S Z, et al. U-Pb zircon age and geochemical constraints on tectonic evolution of the Paleozoicaccretionary orogenic system in the Tongbai orogen, central China. Tectonophysics, 2013, 599: 67-88

11 Zheng Y F, Fu B, Gong B, et al. Stable isotope geochemistry of ultrahigh pressure metamorphic rocks from the Dabie-Sulu orogen in China: Implications for geodynamics and fluid regime. Earth Sci Rev, 2003, 62: 105-161

12 Xue F, Lerch M F, Kroner A, et al. Tectonic evolution of the east Qinling Mountains, China, in the Palaeozoic: A review and new tectonic model. Tectonophysics, 1996, 253: 271-284 
13 Wang H, Wu Y B, Gao S, et al. Continental origin of eclogites in the North Qinling terrane and its tectonic implications. Precambrian Res, 2013, 230: $13-30$

14 胡能高, 赵东林, 徐柏青, 等. 北秦岭含柯石英榴辉岩的发现及其地质意义. 科学通报, 1994, 39: 2013-2016

15 Yang J S, Xu Z Q, Dobrzhinetskaya L F, et al. Discovery of metamorphic diamonds in central China: An indication of a >4000-km-long zone of deep subduction resulting from multiple continental collisions. Terra Nova, 2003, 15: 370-379

16 Zhang J X, Yu S Y, Meng F C, et al. Paired high-pressure granulite and eclogite in collision orogens and their geodynamic implications. Acta Petrol Sin, 2009, 25: 2050-2066

17 Cheng H, Zhang C, Vervoort J D, et al. Timing of eclogite facies metamorphism in the North Qinling by U-Pb and Lu-Hf geochronology. Lithos, 2012, 136-139: 46-59

18 Shi Y, Yu J H, Tectonic evolution of the Qinling orogenic belt, Central China: New evidence from geochemical, zircon U-Pb geochronology and Hf isotopes. Precambrian Res, 2013, 231: 19-60

19 Wang H, Wu Y B, Gao S, et al. Eclogite origin and timings in the North Qinling terrane, and their bearing on the amalgamation of the South and North China Blocks. J Metamorph Geol, 2011, 29: 1019-1031

20 Bader T, Ratschbacher L, Franz L, et al. The Heart of China revisited, I. Proterozoic tectonics of the Qin Mountains in the core of supercontinent Rodinia. Tectonics, 2013, doi: 10.1002/tect.20024

21 陈丹玲，刘良，孙勇，等。北秦岭松树沟高压基性麻粒岩锆石的 LA-ICP-MS U-Pb 定年及其地质意义. 科学通报，2004，49: 1901-1908

22 苏犁，宋述光，宋彪，等. 松树沟地区石榴辉石岩和富水杂岩 SHRIMP 锆石 U-Pb 年龄及其对秦岭造山带构造演化的制约. 科学通 报, 2004, 49: 1209-1211

23 Wang H, Wu Y B, Gao S, et al. Silurian granulite-facies metamorphism, and coeval magmatism and crustal growth in the Tongbai orogen, central China. Lithos, 2011, 125: 249-271

24 Cheng H, King R L, Nakamura E, et al. Transitional time of oceanic to continental subduction in the Dabie orogen: Constraints from U-Pb, Lu-Hf, Sm-Nd and Ar-Ar multichronometric dating. Lithos, 2009, 110: 327-342

25 Liu X C, Wu Y B, Gao S, et al. Zircon U-Pb and Hf evidence for coupled subduction of oceanic and continental crust during the Carboniferous in the Huwan shear zone, western Dabie orogen, central China. J Metamorph Geol, 2011, 29: 233-249

26 Wu Y B, Hanchar J M, Gao S, et al. Age and nature of eclogites in the Huwan shear zone, and the multi-stage evolution of the QinlingDabie-Sulu orogen, central China. Earth Planet Sci Lett, 2009, 277: 345-354

27 Mattauer M, Matte P, Malavieille J, et al. Tectonics of the Qinling belt: Build-up and evolution of eastern Asia. Nature, 1985, 317: 496-500

28 Li S G, Xiao Y L, Liou D L, et al. Collision of the North China and Yangtze Blocks and formation of coesite-bearing eclogites: Timing and processes. Chem Geol, 1993, 109: 89-111

29 Liu F L, Liou J G. Zircon as the best mineral for P-T-time history of UHP metamorphism: A review on mineral inclusions and U-Pb SHRIMP ages of zircons from the Dabie-Sulu UHP rocks. J Asian Earth Sci, 2011, 40: 1-39

30 Wu Y B, Gao S, Zhang H F, et al. Timing of UHP metamorphism in the Hong'an area, western Dabie Mountains, China: Evidence from zircon U-Pb age, trace element and Hf isotope composition. Contrib Mineral Petrol, 155: 123-133

31 Enkin R J, Courtillot V, Leloup P, et al. The paleomagnetic record of Uppermost Permian, Lower Triassic rocks from the South China Block. Geophys Res Lett, 1992, 19: 2147-2150

32 Zhao X X, Coe R S. Paleomagnetic constraints on the collision and rotation of north and south China. Nature, 1987, 327: 141-144

33 Li S Z, Kusky T M, Zhao G C, et al. Two stage Triassic exhumation of HP-UHP terranes in the western Dabie orogen of China: Constraints from structural geology. Tectonophysics, 2010, 490: 267-293 